\title{
Protective Effect of Kaempferol on Cultured Neuroglial Cells Damaged by Induction of Ischemia-like Condition
}

\author{
Young-Woo Son ${ }^{1}$, Yu-Ran Choi ${ }^{2}$ and Young-Mi Seo ${ }^{3, \uparrow}$ \\ ${ }^{1}$ Sanbon Hospital, School of Medicine, Wonkwang University, Gunpo 15865, Korea \\ ${ }^{2}$ Department of Physical Therapy, Graduate School of Daejeon University, Daejeon 35235, Korea \\ ${ }^{3}$ Department of Nursing, College of Medicine, Seonam University, Namwon 55724, Korea
}

This study was performed to evaluate the cytotoxicity induced by ischemia-like condition (ILC) in cultured neuroglial cells (C6 glioma cells). The protective effect of kaempferol (KAE), flavonoid against the cytotoxicity induced by ILC induction was assessed. In addition, antioxidative effects of KAE were done by colorimetric assays. Cell viability and the antioxidative effects such as DPPH-radical scavenging activity, superoxide dismutase (SOD)-like activity and inhibitory activity of lipid peroxidation (LP) were analyzed. ILC induction decreased cell viability in a dose-dependent manner, and the $\mathrm{XTT}_{90}$ value (low cytotoxicity value) and $\mathrm{XTT}_{50}$ value (high cytotoxicity value) were determined during ILC induction for 15 and 40 minutes, respectively. The butylated hydroxytoluene (BHT) antioxidant significantly increased cell viability damaged by the ILC-induced cytotoxicity. In the protective effect of KAE on ILC-induced cytotoxicity, KAE protected the ILC-induced cytotoxicity by the significant increase of cell viability, and also it showed DPPH-radical scavenging ability, SOD-like ability and inhibitory ability of LP. From these results, it is suggested that ILC induction showed cytotoxicity in these cultures and the oxidative stress is involved in the ILC-induced cytotoxicity. While, KAE prevented ILC-induced cytotoxicity by antioxidative effects. In conclusion, natural products like KAE may be a putative therapeutic agent for the treatment of disease associated with oxidative stress such as ischemia.

Key Words: Ischemia, Flavonoid, Cytotoxicity, Antioxidative effect

\section{서 론}

허혈(ischemia)은 혈관의 폐색이나 협착에 의한 일시적 인 혈액공급의 부족을 의미하는데, 뇌허혈은 뇌혈관의 출 혈과 함께 뇌졸중(stroke)의 중요한 요인의 하나로 작용한 다(Lee and Kim, 2006). 뇌조직에서 혈관이상에 의한 허혈 은 뇌세포를 산소결핍상태로 만들며 이 상태가 오랫동안 지속되면 결국 뇌세포는 사멸된다(Lee et al., 2005). 뇌 구 성 세포 중 신경교세포는 신경세포에 영양공급, 재생 및
정화기능을 가지고 있으며, 허혈과 같은 변병 시 회복을 위한 항상성 역할을 수행한다. 따라서 신경교세포가 손상 되면 뇌세포의 사멸이 더욱 촉진된다(Endoh et al., 1994). 허혈 유발과 관련이 깊은 뇌혈관 질환의 가장 대표적인 병 인의 하나인 죽상경화증(atherosclerosis)은 내피손상을 비롯 하여 지질침착의 증가, 결합조직성분의 합성 증가와 같은 병리적 증상을 나타낸다고 알려져 있다(Jialal and Devaraj, 1996). 또한 죽상경화증이 노출된 동맥내막은 혈소판의 유 착과 응집현상이 반복되면서 혈전이 더욱 빠르게 진행되 고(Hamsten et al., 1994), 진행과정 중에 thromboxane $\mathrm{A}_{2}$ 와

* Received: November 22, 2017 / Revised: December 19, 2017 / Accepted: December 19, 2017

${ }^{\dagger}$ Corresponding author: Young-Mi Seo. Department of Nursing, College of Medicine, Seonam University, Namwon 55724, Korea. Tel: +82-63-620-0102, Fax:+82-63-620-0154, e-mail: dudn0408@naver.com

(C) The Korean Society for Biomedical Laboratory Sciences. All rights reserved.

(C) This is an Open Access article distributed under the terms of the Creative Commons Attribution Non-Commercial License (http://creativecommons.org/licenses/by-nc/3.0/) which permits unrestricted non-commercial use, distribution, and reproduction in any medium, provided the original work is properly cited. 
같은 혈관활성물질이 생성 분비되면서 혈소판의 응집이 더욱 가속화된다(Schwartz et al., 1990). 그러나 정상 시에 는 위의 반응과 함께 arachidonic acid가 산화되어 prostaglandin으로 변환되는 대사과정 중에 생성된 물질들이 혈 관수축의 주요한 요인으로 작용하여 혈관을 수축시킨다 (Luscher et al., 1991). 이와는 반대로 혈관내피에서는 arachidonic acid가 prostacyclin (PGI)으로 전환되는 대사작용이 일어나면서 혈관확장작용을 일으키게 된다(Sellke et al., 1990). 이와 같이 혈관의 이완과 수축이 상호협력하여 혈 소판 침착을 방지하는 동시에, 혈관손상에 따른 국소출혈 을 억제한다고 알려져 있다. 허혈 유발에 직접적으로 영 향을 미치는 혈관수축과 확장에는 cyclooxygenase가 관여 하며, 필요 시 이 과정을 조절하는 약물 중 하나인 aspirin 이 대표적인 항혈소판제제로 사용되고 있다(Verbeuren et al., 1986).

허혈에 의한 뇌졸중 유발 시 뇌관류(cerebral perfusion)가 역치 이하로 떨어지면서 ATP 감소 및 lactate의 증가와 같 은 생화학적 변화 및 염증 유발의 위험성이 증가되는데 (Stanimirovic and Satoh, 2000), 이 경우 허혈성 병변의 중심 부위에서는 경색(infarction)이 일어나는 반면, 주변부는 아 직 소생의 기회가 남아 있는 일시적 허혈상태로 빠진다. 따라서 이 같은 상태를 조기 발견하여 치료하는 것은 뇌 졸중 치료에 주된 치료적 방법의 하나이다(Lee et al., 2006).

위와 같은 원인현상에 의하여 유발된 허혈상태에서는 자유라디칼(free radical)이 많이 발생되고, 이로 인해 뇌세 포는 산화적 손상(oxidative stress)에 의하여 퇴화 내지는 사멸에 이르게 된다(Pellegrini-Giampietro et al., 1990). 따라 서, 허혈 발병 시 과도하게 생성된 자유라디칼을 제거함 으로써 병변의 진행과 가속화를 늦출 수 있기 때문에 허 혈 시에는 혈관의 협착이나 폐쇄 또는 출혈 부위를 치료 하는 한편, 자유라디칼의 영향을 제거하여 치료적 효과를 높이고 있다(Jung, 2009). 자유라디칼은 세포로부터 흥분성 아미노산의 분비는 물론 $\mathrm{Ca}^{2+}$ 과 밀접한 관련이 있는 Nmethyl-D-aspartate (NMDA) 수용체의 과활성, 세포 지질막 의 과산화 및 질소라디칼과의 반응에 의한 peroxynitrite라 는 독성물질의 생성과 같은 세포퇴화 현상을 유발한다고 알려져 있다(Lee et al., 2005).

최근, 천연물의 성분 중에 자유라디칼을 제거하는 항산 화 물질을 비롯하여 항균이나 항암, 항독에 유효한 생리 활성물질이 다량 함유되어 있음이 밝혀지고 있다. 예를 들 어 flavonoid와 같은 페놀화합물(phenolic compound)을 비 롯하여 carotenoids와 같은 isoprenoid 및 sphingolipid와 같<smiles>O=c1c(O)c(-c2ccc(O)cc2)oc2cc(O)cc(O)c12</smiles>

Fig. 1. The structure of Kaempferol (KAE)

은 배당체 등 많은 성분들이 추출 정제되어 있다(Li et al., 2007). 특히 flavonoid 계통이 속하는 페놀화합물은 isoprenoid와 함께 식물에서 가장 많이 분포된 성분 중의 하나 로 알려져 있다(Wang et al., 2006).

Kaempferol (KAE)은 과일이나 채소를 비롯하여 연꽃과 같은 여러 식물들로부터 분리되는 flavonoid 계통의 성분 중 하나로 3 개의 링(ring)으로 구성된 분자구조를 형성하 고 있다(Fig. 1). 이들의 각 링에는 1개 또는 그 이상의 수 산기(-OH)를 가지고 있어 다른 성분과의 결합력이 강함으 로써 강력한 항산화능을 비롯하여 항암이나 항염작용이 뛰어나다고 알려져 있다(Gates et al., 2007). 그럼에도 불구 하고 아직까지 $\mathrm{KAE}$ 에 대한 항산화에 대한 연구는 많이 되어 있지 않으며, 더욱이 배양세포를 대상으로 한 연구 는 찾아보기 어렵다(Kim et al., 2010). 배양세포는 생체세포 처럼 화학적 특성과 형태가 같고 상호 동질적이며 숫자적 으로 많아 여러 번의 번복 실험이 가능하여 재현성이 뛰 어나다는 이점이 있다. 더욱이 동물의 희생 없이도 실험 재료의 확보가 가능하다는 장점이 있다(Kim and Jekal, 2016). 따라서 본 연구는 허혈에 유효한 천연소재의 탐색 을 위한 일환으로 실험적으로 허혈을 유도한 배양 신경교 세포의 일종인 C6 glioma 세포를 재료로 허혈에 대한 세 포독성을 분석하고 이와 동시에 이에 대한 $\mathrm{KAE}$ 의 영향 을 항산화 측면에서 조사하였다.

\section{재료 및 방법}

\section{세포주}

본 실험에 사용한 신경교세포인 C6 glioma 세포주는 American Type Culture Collection (ATCC)에서 분양 받아 사용하였다. 


\section{약제 제조}

본 실험에 사용한 시약으로 $\mathrm{KAE}$ 을 비롯한 trypsin, pyrogallol, butylated hydroxytoluene (BHT), isopropanol, ferrous chloride, ethylenediaminetetraacetic acid (EDTA), hydrogen chloride ( $\mathrm{HCl})$, vitamin E, 1,1-diphenyl-2-picrylhydrazyl (DPPH), phosphate-buffered saline (PBS), dimethylsulfoxide (DMSO), linoleic acid, ammonium thiocyanate, 및 2,3-bis-(2-methoxy4-nitro-5-sulfophenyl)-2H-tetra-zolium-5-carboxanilide (XTT) 는 Sigma사(St. Louis. MO, U.S.A.)에서 구입하였다. 또한, Hanker's balanced salt solution (HBSS)과 fetal bovine serum (FBS) 및 minimum essential medium (MEM)은 Gibco사 (Grand Island, NY, U.S.A.)에서 구입하였다. KAE의 제조는 $\mathrm{FBS}$ 가 없는 $\mathrm{MEM}$ 을 사용하여 각각 $50 \mu \mathrm{M}, 100 \mu \mathrm{M}, 250$ $\mu \mathrm{M}$ 및 $500 \mu \mathrm{M}$ 의 저장액을 만들어 희석하여 사용하였다. XTT는 PBS를 이용하여 $50 \mu \mathrm{g} / \mathrm{ml}$ 의 저장액을 만든 후 냉 암소에 보관한 다음 필요한 양을 직접 배양액에 첨가하여 사용하였다.

\section{세포 배양}

신경교세포(C6 glioma cell)의 배양은 Oh et al. (2012)의 방 법에 따라 배양용기에 부착된 세포를 $0.025 \%$ trypsin을 사 용하여 분리하였다. 분리된 세포들은 원침 후 $10 \% \mathrm{FBS}$ 가 함유된 MEM 배양액에 넣고 $1 \times 10^{5}$ cells/well이 되도록 조절한 후 96-well 배양용기에 배분하였다. 배분된 세포들 은 $36^{\circ} \mathrm{C}, 5 \% \mathrm{CO}_{2}$ 로 조절된 항온기 내에서 72 시간 동안 배 양하였다.

\section{허혈 유도(ischemia-like condition, ILC)}

배양중인 C6 glioma 세포를 HBSS로 3회 세척한 후 $\mathrm{N}_{2}$ 와 $\mathrm{CO}_{2}$ 가 혼합 조절된 정온기에서 각각 $15 \sim 40$ 분 동안 배양한 후 세포생존율에 의해 $\mathrm{XTT}_{90}$ 값과 $\mathrm{XTT}_{50}$ 값을 측 정하였다. 또한, 약제의 항산화능에 대한 분석은 ILC 유도 과정에서 측정된 $\mathrm{XTT}_{50}$ 값의 노출에서 행하였다.

\section{$\mathrm{BHT}$ 의 항산화능 측정}

$\mathrm{BHT}$ 의 항산화능을 조사하기 위하여 자유라디칼의 일종 인 $30 \mu \mathrm{M} \mathrm{H} \mathrm{O}_{2}$ 를 배양세포를 처리하기 2시간 전에 BHT 가 20 60 $\mu \mathrm{M}$ 농도로 각각 포함된 배양액에서 세포를 처 리한 후 세포생존율을 대조군과 비교 조사하였다.

\section{ILC 유도에 대한 항산화제의 영향}

ILC 유도에 대한 BHT의 영향을 조사하기 위하여 배양 중인 C6 glioma 세포에 ILC 유도 2시간 전에 BHT가 40 $60 \mu \mathrm{M}$ 농도로 각각 포함된 배양액에서 세포를 처리한 후 세포생존율을 ILC 유도군과 비교 조사하였다.

\section{ILC에 대한 KAE의 영향}

$\mathrm{ILC}$ 를 배양세포에 유도하기 2시간 전에 $\mathrm{KAE}$ 가 $180 \mu \mathrm{M}$ 과 $200 \mu \mathrm{M}$ 로 각각 포함된 배양액에서 세포를 배양한 다 음 세포생존율에 의하여 대조군과 비교 조사하였다.

\section{$\mathrm{DPPH}$-라디칼 소거 활성(DPPH-radical scavenging activity) 측정}

$\mathrm{DPPH}$-라디칼 소거 활성의 측정은 Blois (1958)의 방법 에 따라, 메탄올시료에 $0.3 \mathrm{mM} \mathrm{DPPH}$ 메탄올용액 $100 \mu \mathrm{L}$ 를 첨가하여 실온에서 30 분간 처리하였다. 처리 완료 후 ELISA reader (Spectra max 250, Molecular Devices, Sunnyvale, U.S.A.)로 $517 \mathrm{~nm}$ 에서 흡광도를 측정하였다. 라디칼 소거 활성은 시료첨가군과 시료무첨가군간의 차이를 시료무첨 가군에 의한 백분율로 나타냈다. 또한 $\mathrm{BHT}$ 의 활성을 양 성대조군으로 사용하였다.

\section{Superoxide dismutase (SOD)-유사 활성 측정}

SOD-유사 활성은 Marklund \& Marklund (1974)의 방법 에 따라 행하였다. 즉, 시료에 Tris-HCl buffer와 $10 \mathrm{mM}$ pyrogallol을 가하고 $25^{\circ} \mathrm{C}$ 에서 10 분 동안 처리하였다. 처리 완료 후 $1 \mathrm{~N} \mathrm{HCl}$ 로 반응시킨 다음 ELISA reader (Spectra $\max$ 250, Molecular Devices, Sunnyvale, U.S.A.)로 $420 \mathrm{~nm}$ 에 서 흡광도를 측정하였다. 유사 활성의 측정은 시료첨가군 과 무첨가군의 차이에 의한 백분율로 표시하였다. 또한 $\mathrm{BHT}$ 의 활성을 양성대조군으로 사용하였다.

\section{지질과산화(lipid peroxidation, LP) 활성 측정}

LP 활성 측정은 Kikuzaki \& Nakatani (1993)의 방법에 따 라, $2.52 \%$ linoleic acid와 $0.05 \mathrm{M} \mathrm{PBS}(\mathrm{pH} 7.0)$ 용액 $12.1 \mathrm{ml}$ 에 에탄올과 시료 $3.9 \mathrm{ml}$ 혼합액을 첨가한 후 24시간 동 안 $40{ }^{\circ} \mathrm{C}$ 에서 배양하였다. 배양 완료 후 에탄올과 $30 \%$ ammonium thiocyanate와 $0.02 \mathrm{M}$ ferrous chloride를 $0.1 \mathrm{ml}$ 를 넣은 후 실온에서 3 분 동안 반응시켰다. 반응 후 ELISA reader (Spectra max 250, Molecular Devices, Sunnyvale, U.S.A.) 로 $500 \mathrm{~nm}$ 에서 흡광도를 측정하였다. 
Table 1. The cytotoxicity of cultured C6 glioma cells exposed by ischemia-like condition (ILC) by XTT assay

\begin{tabular}{ccccc}
\hline \hline \multirow{2}{*}{$\begin{array}{c}\text { Incubation time } \\
\text { of ILC (min) }\end{array}$} & XTT assay $(450 \mathrm{~nm})$ & & $P$ \\
\cline { 2 - 2 } Control $^{\text {Mean } \pm \mathrm{SD}}$ & & & \\
\hline $15\left(\mathrm{XTT}_{90}\right)$ & $0.54 \pm 0.06$ & & \\
20 & $0.49 \pm 0.03$ & & \\
25 & $0.39 \pm 0.02$ & & \\
30 & $0.37 \pm 0.02$ & 68.23 & .000 \\
35 & $0.35 \pm 0.03$ & & \\
$40\left(\mathrm{XTT}_{50}\right)$ & $0.31 \pm 0.02$ & & \\
\hline
\end{tabular}

Cultured C6 glioma cells were exposed to ILC for 15 40 min., respectively. The data indicate the mean \pm SD for triplicate experiments. Significantly different from the control.

\section{통계 처리}

실험 결과는 SPSS/WIN 18.0을 이용하여 군간의 차이 를 비교하기 위하여 ANOVA를 시행하였고 사후 분석은 Tukey's HSD로 하였다. 모든 통계의 유의수준은 $P$-value가 0.05 미만의 경우를 유의한 것으로 채택하였다.

\section{결 과}

\section{ILC 유도에 대한 세포독성 측정}

$\mathrm{ILC}$ 유도에 대한 $\mathrm{XTT}_{90}$ 값과 $\mathrm{XTT}_{50}$ 값의 측정을 위하 여 배양세포를 15 40분 동안 각각 $\mathrm{ILC}$ 에 노출을 유도한 결과, 15 분간 노출의 경우 세포생존율이 대조군인 $100 \%$ $(0.54 \pm 0.06)$ 에 비하여 $90.7 \%(0.49 \pm 0.03)$ 로 나타났으며 20 분간 노출의 경우 $72.2 \%(0.39 \pm 0.02)$ 로 나타났다. 또한, 25 분간 노출의 경우 세포생존율은 $68.5 \%(0.37 \pm 0.02)$ 로 나 타났다. 한편, 배양세포를 30 분 동안 ILC에 노출한 결과 세포생존율이 $64.8 \%(0.35 \pm 0.03)$ 로 나타났으며, 35 분 동안 노출에서는 $57.4 \%(0.31 \pm 0.02)$ 로 나타났다. 또한, 40 분 동안 노출에 있어서 세포생존율은 $50.4 \%(0.27 \pm 0.01)$ 로 나타났 다. 위의 결과에서 15 40분 동안 배양세포를 ILC에 노출 한 결과 저독성(low cytotoxicity) 값인 $\mathrm{XTT}_{90}$ 값은 15 분 노 출에서 나타난데 비하여 고독성(high cytotoxicity) 값인 $\mathrm{XTT}_{50}$ 값은 40 분 노출에서 나타났다 $(P<0.001)$ (Table 1). $\mathrm{ILC}$ 유도를 위한 노출 시간에 따른 사후분석 결과 대조군 과 15 분 노출은 통계적으로 차이가 없었다. 20 분, 25 분, 30 분 노출 시에도 통계적으로 차이가 없었으나 대조군과 15 분 노출보다 세포생존율이 유의하게 감소되었음을 알
Table 2. The antioxidative activity of butylated hydroxytoluene (BHT) on the hydrogen peroxide $\left(\mathrm{H}_{2} \mathrm{O}_{2}\right)$ in cultured $\mathrm{C} 6$ glioma cells

\begin{tabular}{ccccc}
\hline \hline \multirow{2}{*}{$\begin{array}{c}\text { Concentrations } \\
\text { of BHT }(\mu \mathrm{M})\end{array}$} & XTT assay $(450 \mathrm{~nm})$ & & $P$ \\
\cline { 2 - 2 } Control & Mean $\pm \mathrm{SD}$ & & \\
\hline $30 \mathrm{H}_{2} \mathrm{O}_{2}$ & $0.27 \pm 0.02$ & & \\
20 & $0.10 \pm 0.02$ & & \\
40 & $0.17 \pm 0.01$ & 52.27 & .000 \\
60 & $0.22 \pm 0.03$ & & \\
\hline
\end{tabular}

Cultured C6 glioma cells were pretreated with $20 \mu \mathrm{M}, 40 \mu \mathrm{M}$ and $60 \mu \mathrm{M}$ of BHT for 2 hours. The data indicate the mean \pm SD for triplicate experiments. Significantly different from $\mathrm{H}_{2} \mathrm{O}_{2}$-treated group.

수 있었다. 또한 30 분과 35 분에서 통계적으로 차이가 없 으나 대조군, $15 \sim 25$ 분 노출과는 통계적으로 유의한 차이 를 보였다. 또한 35 분과 40 분 노출에서도 통계적으로 유 의한 차이가 없으나, 40 분 노출이 대조군, 15 30분 노출과 는 통계적으로 유의한 차이를 보이는 것을 알 수 있었다.

\section{$\mathrm{BHT}$ 의 항산화능 측정}

BHT를 양성대조군으로 사용하기 위하여 BHT의 항산 화능을 조사한 결과, $30 \mu \mathrm{M}$ 의 $\mathrm{H}_{2} \mathrm{O}_{2}$ 만을 처리한 경우 대조 군에 비하여 세포생존율이 $37.0 \%(0.10 \pm 0.02)$ 로 나타난 반 면, $20 \mu \mathrm{M}$ 과 $40 \mu \mathrm{M}$ 의 $\mathrm{BHT}$ 의 처리에서는 각각 $63.0 \%$ (17 $\pm 0.01)$ 와 $81.5 \%(0.22 \pm 0.03)$ 로 나타났다. 또한, $60 \mu \mathrm{M}$ 농 도의 $\mathrm{BHT}$ 의 처리에서는 $88.9 \%(0.24 \pm 0.04)$ 로 나타나 통 계적으로 유의한 차이가 나타났다 $(P<0.001)$ (Table 2). BHT 의 농도별 항산화능에 대한 사후분석 결과 대조군과 60 $\mu \mathrm{M} \mathrm{BHT}$ 는 통계적으로 차이가 없이 세포생존율이 가장 높았으며, $40 \mu \mathrm{M}$ 과 $60 \mu \mathrm{M}$ 도 통계적으로 차이가 없이 그 다음으로 세포생존율이 높았다. 그러나 대조군과 $40 \mu \mathrm{M}$ $\mathrm{BHT}$ 는 통계적으로 유의한 차이가 있었다. 이어서 $20 \mu \mathrm{M}$ BHT, $30 \mu \mathrm{M} \mathrm{H}_{2} \mathrm{O}_{2}$ 순으로 세포생존율이 통계적으로 유의 하게 감소하는 것을 알 수 있었다. 따라서, $\mathrm{BHT}$ 의 농도가 높을수록 $\mathrm{H}_{2} \mathrm{O}_{2}$ 에 대한 항산화능이 증가함을 알 수 있었다.

\section{ILC 유도에 대한 항산화제의 영향}

ILC 유도에 대한 항산화제의 영향을 알아본 결과, ILC 유도의 경우 세포생존율이 대조군에 비하여 38.5\% (0.05土 $0.02)$ 로 나타난 것에 비하여 $40 \mu \mathrm{M}$ 과 $60 \mu \mathrm{M}$ 의 $\mathrm{BHT}$ 의 처 리에서는 각각 $69.2 \%(0.09 \pm 0.02)$ 와 $84.6 \%(0.11 \pm 0.03)$ 로 
Table 3. The effect of butylated hydroxytoluene (BHT) on the cytotoxicity induced by ischemia like condition (ILC) in cultured C6 glioma cells

\begin{tabular}{ccccc}
\hline \hline \multirow{2}{*}{$\begin{array}{c}\text { Concentrations } \\
\text { of BHT }(\mu \mathrm{M})\end{array}$} & XTT assay $(450 \mathrm{~nm})$ & & \\
\cline { 2 - 2 } & Mean $\pm \mathrm{SD}$ & & $P$ \\
\hline Control & $0.13 \pm 0.02$ & & \\
ILC & $0.05 \pm 0.02$ & & 18.92 & .000 \\
40 & $0.09 \pm 0.02$ & & \\
60 & $0.11 \pm 0.03$ & & \\
\hline
\end{tabular}

Cultured C6 glioma cells were pretreated with $40 \mu \mathrm{M}$ and $60 \mu \mathrm{M}$ of BHT for 2 hours. The data indicate the mean \pm SD for triplicate experiments. Significantly different from ILC-treated group.

Table 4. The protective effect of kaempferol (KAE) on ischemialike condition (ILC)-induced cytotoxicity in cultured C6 glioma cells

\begin{tabular}{ccccc}
\hline \hline \multirow{2}{*}{$\begin{array}{c}\text { Concentrations } \\
\text { of KAE }(\mu \mathrm{M})\end{array}$} & XTT assay $(450 \mathrm{~nm})$ & & \\
\cline { 2 - 2 } & Mean $\pm \mathrm{SD}$ & & $P$ \\
\hline Control & $0.37 \pm 0.03$ & & \\
ILC & $0.13 \pm 0.01$ & & 139.50 & .000 \\
180 & $0.23 \pm 0.02$ & & \\
200 & $0.28 \pm 0.03$ & & \\
\hline
\end{tabular}

Cultured C6 glioma cells were pretreated with $180 \mu \mathrm{M}$ and 200 $\mu \mathrm{M}$ of KAE for 2 hours. The data indicate the mean \pm SD for triplicate experiments. Significantly different from the ILC-treated group.

나타나 모두 ILC 유도에 비하여 유의한 증가를 보였다 $(P<0.001)$ (Table 3). ILC 유도에 대한 BHT 농도에 따른 사후검정 결과 대조군과 $60 \mu \mathrm{M} \mathrm{BHT}$ 는 통계적으로 차이가 없이 세포생존율이 가장 높았으며, $40 \mu \mathrm{M} \mathrm{BHT}$ 는 $60 \mu \mathrm{M}$ 과 통계적으로 차이는 없었으나 대조군과는 통계적 차이를 보였다. 그리고 ILC 유도가 세포생존율이 통계적으로 가 장 낮은 것을 확인하였다.

\section{ILC 유도에 대한 $\mathrm{KAE}$ 의 영향}

$\mathrm{KAE}$ 가 ILC 유도에 미치는 영향을 조사한 결과, ILC 유 도만의 처리에서는 세포생존율이 대조군에 비하여 $35.1 \%$ $(0.13 \pm 0.01)$ 로 나타난데 비하여 $180 \mu \mathrm{M} \mathrm{KAE}$ 의 처리에서 는 $62.2 \%(0.23 \pm 0.02)$ 로 나타났다. 또한 $200 \mu \mathrm{M}$ 처리에서 는 75.7\% (0.28 \pm 0.03$)$ 로 나타나 모두 ILC 유도 처리에 비 하여 매우 유의한 증가를 보였다 $(P<0.001)$ (Table 4). $\mathrm{KAE}$ 가 ILC 유도에 미치는 영향에 대한 사후검정 결과 대조

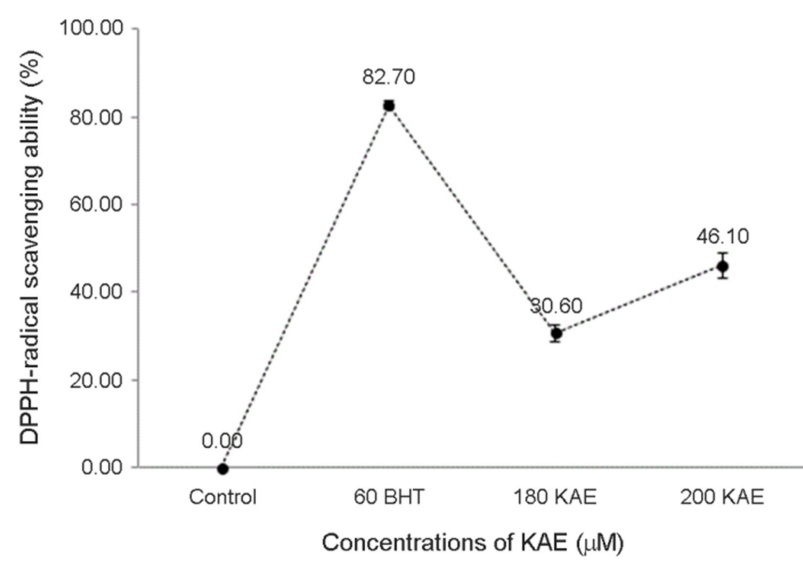

Fig. 2. DPPH-radical scavenging ability of KAE at concentrations of $180 \mu \mathrm{M}$ and $200 \mu \mathrm{M}$, respectively. The data indicate the mean \pm SD for triplicate experiments. Significantly different from the control. BHT was used as positive control.

Table 5. The DPPH-radical scavenging activity of kaempferol (KAE) determined at a wavelength of $517 \mathrm{~nm}$

\begin{tabular}{ccccc}
\hline \hline \multirow{2}{*}{$\begin{array}{c}\text { Concentrations } \\
\text { of KAE }(\mu \mathrm{M})\end{array}$} & $\begin{array}{c}\text { DPPH-radical scavenging } \\
\text { activity }(517 \mathrm{~nm})\end{array}$ & $F$ & $P$ \\
\cline { 2 - 2 } & Mean \pm SD & & \\
\hline Control & $1.73 \pm 0.24$ & & \\
60 BHT & $0.30 \pm 0.04$ & & 129.74 & .000 \\
180 & $1.20 \pm 0.09$ & & & \\
200 & $0.93 \pm 0.14$ & &
\end{tabular}

The data indicate the mean \pm SD for triplicate experiments. Significantly different from the control. BHT was used as positive control.

군, ILC 유도군, $180 \mu \mathrm{M} \mathrm{KAE}, 200 \mu \mathrm{M} \mathrm{KAE}$ 순으로 세포생 존율이 높은 것을 알 수 있었다.

\section{$\mathrm{DPPH}$-라디칼 소거 활성 측정}

$\mathrm{DPPH}$-라디칼 소거 활성 측정 결과 $180 \mu \mathrm{M} \mathrm{KAE}$ 농도 처리에서는 대조군에 비하여 활성이 $69.4 \%$ (1.20土0.09)로 나타났으며, $200 \mu \mathrm{M}$ 의 처리에서는 $53.9 \%(0.93 \pm 0.14)$ 로 나 타났다(Table 5). 따라서, $180 \mu \mathrm{M}$ 과 $200 \mu \mathrm{M}$ 에서 소거능은 각각 $30.6 \%$ 와 $46.1 \%$ 로 나타나 모두 대조군에 비하여 통 계적으로 유의한 DPPH-라디칼 소거능을 보였다 $(P<0.001)$. 특히, $200 \mu \mathrm{M} \mathrm{KAE}$ 의 DPPH-라디칼 소거능은 $82.7 \%(0.30$ $\pm 0.04)$ 의 DPPH-라디칼 소거능을 보인 $60 \mu \mathrm{M} \mathrm{BHT}$ 의 $50 \%$ 이상인 것으로 나타났다(Fig. 2). 사후검정 결과 $60 \mu \mathrm{M}$ $\mathrm{BHT}, 200 \mu \mathrm{M} \mathrm{KAE}, 180 \mu \mathrm{M} \mathrm{KAE}$, 대조군 순으로 DPPH-라 
Table 6. The superoxide dismutase (SOD)-like activity of kaempferol (KAE) determined at a wavelength of $420 \mathrm{~nm}$

\begin{tabular}{ccccc}
\hline \hline \multirow{2}{*}{$\begin{array}{c}\text { Concentrations } \\
\text { of KAE }(\mu \mathrm{M})\end{array}$} & $\begin{array}{c}\text { SOD-like activity } \\
(420 \mathrm{~nm})\end{array}$ & $F$ & $P$ \\
\cline { 2 - 2 } & Mean $\pm \mathrm{SD}$ & & \\
\hline Control & $0.22 \pm 0.03$ & & \\
$60 \mathrm{BHT}$ & $0.37 \pm 0.03$ & & 51.71 & .000 \\
180 & $0.23 \pm 0.03$ & & & \\
200 & $0.26 \pm 0.03$ & &
\end{tabular}

The data indicate the mean \pm SD for triplicate experiments. Significantly different from the control. BHT was used as positive control.

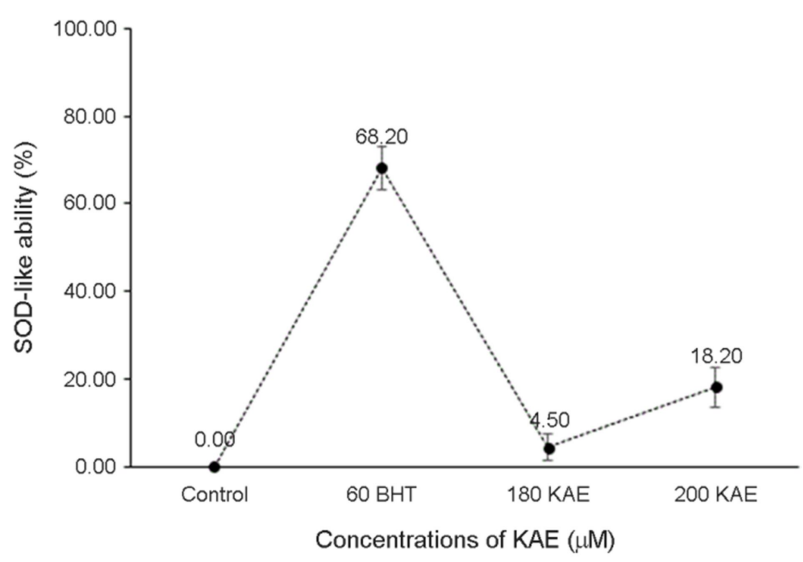

Fig. 3. The SOD-like ability of KAE at concentrations of $180 \mu \mathrm{M}$ and $200 \mu \mathrm{M}$, respectively. The data indicate the mean \pm SD for triplicate experiments. Significantly different from the control. BHT was used as positive control.

디칼 소거능이 높은 것으로 나타났다.

\section{$\mathrm{SOD}-$ 유사 활성 측정}

$\mathrm{KAE}$ 에 대한 SOD-유사 활성 측정을 위하여 $180 \mu \mathrm{M}$ 과 $200 \mu \mathrm{M}$ 농도의 $\mathrm{KAE}$ 를 각각 분석한 결과 $180 \mu \mathrm{M}$ 의 처리 에서는 대조군에 비하여 유사 활성이 $104.5 \%(0.23 \pm 0.03)$ 로 나타났다. 이에 비하여 $200 \mu \mathrm{M}$ 의 처리에서는 $118.2 \%$ $(0.26 \pm 0.03)$ 로 나타났다(Table 6). 따라서, SOD-유사 활성능 은 $180 \mu \mathrm{M}$ 과 $200 \mu \mathrm{M}$ 에서 각각 $4.5 \%$ 와 $18.2 \%$ 로 나타나 대조군에 비하여 모두 유의한 유사 활성능을 나타냈다 $(P<0.001)$. 특히, $200 \mu \mathrm{M}$ 에서의 유사 활성능은 양성대조군 인 $60 \mu \mathrm{M}$ BHT 활성능 값인 $68.2 \%(0.37 \pm 0.03)$ 에 대한 $26.7 \%$ 인 것으로 나타났다(Fig. 3). 사후검정 결과 대조군 과 $180 \mu \mathrm{M} \mathrm{KAE}$ 는 통계적으로 유의한 차이가 없었으며,
Table 7. The lipid peroxidation (LP) of kaempferol (KAE) determined at a wavelength of $500 \mathrm{~nm}$

\begin{tabular}{ccccc}
\hline \hline \multirow{2}{*}{$\begin{array}{c}\text { Concentrations } \\
\text { of KAE }(\mu \mathrm{M})\end{array}$} & $\begin{array}{c}\text { Lipid peroxidation } \\
(500 \mathrm{~nm})\end{array}$ & $F$ & $P$ \\
\cline { 2 - 2 } & Mean $\pm \mathrm{SD}$ & & \\
\hline Control & $0.44 \pm 0.03$ & & \\
60 BHT & $0.07 \pm 0.02$ & & 197.74 & .000 \\
180 & $0.25 \pm 0.01$ & & & \\
200 & $0.16 \pm 0.02$ & & \\
\hline
\end{tabular}

The data indicate the mean \pm SD for triplicate experiments. Significantly different from the control.

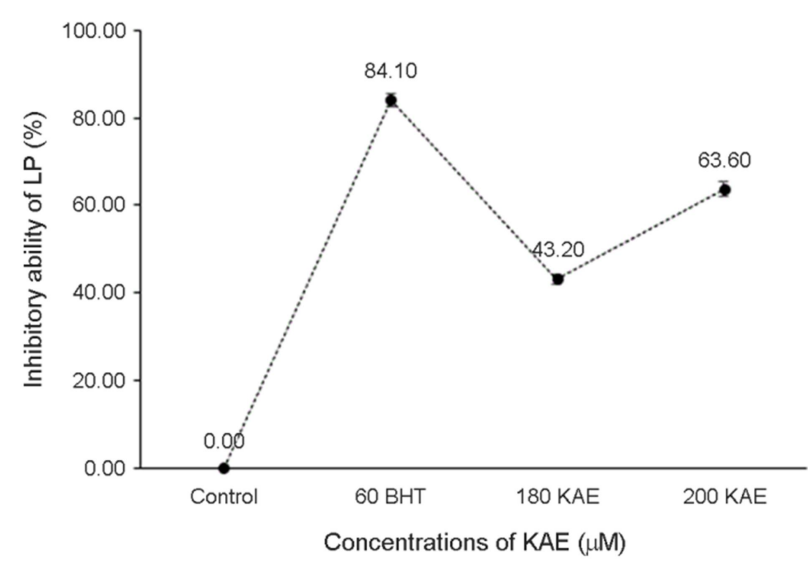

Fig. 4. The inhibitory activity of LP in KAE at concentrations of $180 \mu \mathrm{M}$ and $200 \mu \mathrm{M}$, respectively. The data indicate the mean \pm SD for triplicate experiments. Significantly different from the control. BHT was used as positive control.

$180 \mu \mathrm{M} \mathrm{KAE}$ 와 $200 \mu \mathrm{M} \mathrm{KAE}$ 간에도 통계적으로 유의한 차이가 없었으나, 대조군과 $200 \mu \mathrm{M} \mathrm{KAE}$ 는 통계적으로 유 의한 차이가 나타났다.

\section{지질과산화(LP) 활성 측정}

KAE가 LP에 미치는 영향을 조사하기 위하여 $180 \mu \mathrm{M}$ 과 $200 \mu \mathrm{M}$ 의 $\mathrm{KAE}$ 를 처리한 결과 $180 \mu \mathrm{M} \mathrm{KAE}$ 에서 LP 활성이 대조군에 비하여 $56.8 \%(0.25 \pm 0.01)$ 로 나타난데 비 하여, $200 \mu \mathrm{M} \mathrm{KAE}$ 처리에서는 $36.4 \%(0.16 \pm 0.02)$ 의 LP 활 성을 보였다(Table 7). 따라서, LP 억제능은 $180 \mu \mathrm{M}$ 과 200 $\mu \mathrm{M}$ 에서 각각 $43.2 \%$ 와 $63.6 \%$ 로 나타나 이는 모두 대조군 에 유의한 LP 억제능을 보였으며 $(P<0.001)$, 특히, $200 \mu \mathrm{M}$ $\mathrm{KAE}$ 는 $84.1 \%$ 의 LP 억제능을 보인 양성대조군인 $60 \mu \mathrm{M}$ $\mathrm{BHT}$ 의 $75.0 \%$ 이상으로 나타났다(Fig. 4). 사후검정 결과 
$60 \mu \mathrm{M} \mathrm{BHT}, 200 \mu \mathrm{M} \mathrm{KAE}, 180 \mu \mathrm{M} \mathrm{KAE}$, 대조군 순으로 $\mathrm{LP}$ 억제능이 높게 나타났다.

\section{고 찰}

허혈 시 뇌조직에서는 혈관이 일시 좁아져 뇌세포에 저 산소증과 영양공급의 부족을 유발하므로 세포의 손상 내 지는 사멸을 초래하게 된다(Lee et al., 2005). 뇌허혈 시 신 경교세포가 제일 먼저 활성화되어 병적상태에 반응을 보 이는 것은 뇌의 환경 변화에 대한 항상성을 회복하려는 첫 번째 반응세포이기 때문이다(Endoh et al., 1994). 따라서, 본 연구에서는 신경교세포인 C6 glioma 세포를 배양한 후 15 40분 동안 각각 실험적으로 ILC 유도를 시행하여 이 에 대한 영향을 조사하였다. 배양세포를 ILC 유도에 노출 한 결과 처리 시간에 의존적으로 대조군에 비하여 세포생 존율을 점차 감소시켰으며 이 과정에서 ILC 유도 15 분과 40 분 노출에서 각각 저독성(low cytotoxicity) 값인 $\mathrm{XTT}_{90}$ 값과 고독성(high cytotoxicity) 값인 $\mathrm{XTT}_{50}$ 값이 나타났다. $\mathrm{XTT}_{90}$ 과 $\mathrm{XTT}_{50}$ 은 대조군에 비하여 살아 있는 세포 수 대 신 세포 활성이 각각 대조군의 90 과 50 이 되는 값을 의미 한다(Kim et al., 2010). 본 연구 결과는 ILC 유도가 세포독 성을 가지고 있다는 것을 말해주고 있으며 이는 ILC 유 도가 태어난 지 3 일된 신생생쥐 신경세포에 독성을 나타 냈다는 연구 보고와도 일치하였다(Jung, 2009). 허혈 시 저 산소에 의하여 세포괴사가 유발되면 과량의 자유라디칼 이 생성되어 산화적 손상이 발생되는데, 이 결과 세포손 상에 의해 세포생존율의 감소가 초래되었을 것으로 판단 된다(Pellegrini-Giampietro et al., 1990). 따라서, 본 연구에서 는 허혈과 산화적 손상과의 관련성을 조사하기 위하여 먼 저 항산화제의 일종인 $\mathrm{BHT}$ 의 항산화능을 자유라디칼의 일종인 $\mathrm{H}_{2} \mathrm{O}_{2}$ 를 비교군으로 조사하였다. 그 결과 $\mathrm{BHT}$ 는 처리 농도에 비례하여 $\mathrm{H}_{2} \mathrm{O}_{2}$ 만의 처리에 비하여 세포생존 율을 유의하게 증가시켜 높은 항산화능을 나타냈다. BHT 는 vitamin $\mathrm{E}$ 와 같이 hydroxyl radical $(\mathrm{OH})$ 을 비롯한 $\mathrm{H}_{2} \mathrm{O}_{2}$ 및 superoxide $\left(\mathrm{O}_{2}^{-}\right)$와 같은 자유라디칼의 제거능을 가지고 있는 항산화제의 일종으로 알려져 있다(Kim and Jekal, 2016). 한편, 허혈 시에는 nuclear factor-kappa B (NF-kB)와 같은 핵전사인자의 활성과 더불어 이로 인한 활성산소 (reactive oxygen species, ROS)의 폭주, interleukin (IL)-1이나 tumor necrosis factor (TNF)- $\alpha$ 와 같은 사이토카인의 분비 등으로 인하여 병변을 더욱 가속화 시킨다(Gracia-Lopez et al., 2007). 따라서, 본 연구에서는 ILC 유도와 산화적 손상
간의 관련성을 조사하기 위하여 ILC 유도에 대한 BHT의 영향을 조사하였다. 그 결과 BHT의 처리군이 ILC 유도군 에 비하여 유의한 세포생존율의 증가를 보임으로서 방어 효과가 있는 것으로 나타났다. 이 같은 결과는 ILC 유도 에 산화적 손상이 관여하고 있음을 제시하고 있으며, 이 는 이 허혈에 자유라디칼이 관여하고 있다고 보고한 연구 결과와 일치하였다(Pellegrini-Giampietro et al., 1990). 한편, $\mathrm{KAE}$ 는 페놀화합물의 일종으로 flavon을 비롯한 flavanol 및 isoflavon과 같은 flavonoid 계통의 성분으로서 강한 항 산화능을 가지고 있다(Leung et al., 2007). 본 연구에서는 $\mathrm{ILC}$ 유도에 대한 $\mathrm{KAE}$ 의 영향을 조사한 결과 $\mathrm{KAE}, 180$ $\mu \mathrm{M}$ 과 $200 \mu \mathrm{M}$ 의 처리에서 모두 ILC 유도만의 처리에 비 하여 유의한 세포생존율의 증가를 보였다. 본 연구 결과 는 KAE가 ILC 유도로부터 세포손상을 방어한 것으로서 메틸수은의 라디칼에 의한 산화적 손상으로부터 $\mathrm{KAE}$ 가 세포독성을 방어하였다는 연구 보고와도 일치하였다(Kim et al., 2010). 이 같은 결과는 ILC 유도에 의해 유발된 산 화적 손상을 $\mathrm{KAE}$ 가 방어한 결과로 $\mathrm{KAE}$ 의 항산화능을 제시하고 있다(El-Sayed et al., 2001). KAE의 항산화능은 페 놀화합물의 일종인 polyphenol과 같이 라디칼 제거능이 강 한 flavonoid 계통의 성분 활성에 의한 것으로 생각된다 $(\mathrm{Li}$ et al., 2007). 따라서 본 연구에서는 $\mathrm{KAE}$ 의 항산화능을 알 아보기 위하여 DPPH-라디칼 소거능을 비롯하여 SOD-유 사 활성능 및 LP 억제능을 조사하였다. DPPH-라디칼 소 거능에 있어서 $\mathrm{KAE}$ 는 $180 \mu \mathrm{M}$ 과 $200 \mu \mathrm{M}$ 에서 모두 대조 군에 비하여 유의한 라디칼 소거능을 보였다. 본 실험 결 과는 KAE가 라디칼을 제거하는 항산화능이 있음을 말해 주고 있으며, 이 같은 항산화 효과는 위에서와 같이 $\mathrm{KAE}$ 가 페놀화합물 계통에 속하는 flavonoid 계통의 성분에 의 한 것으로 생각된다(Ma et al., 2003). 페놀화합물은 분자구 조에 수산기 $(-\mathrm{OH})$ 를 가지고 있어 이로 인한 결합력이 매 우 뛰어나기 때문에 항산화 및 항염, 항독 등에 유효한 생 리 활성을 나타낸다고 알려져 있다(Krizkova et al., 2000). 한편, $\mathrm{KAE}$ 의 $\mathrm{SOD}$-유사 활성능의 조사를 위한 $180 \mu \mathrm{M}$ 과 $200 \mu \mathrm{M}$ 의 $\mathrm{KAE}$ 처리에서는 대조군에 비하여 모두 높은 유사 활성능을 보였다. 본 실험 결과 $\mathrm{KAE}$ 가 인체의 항산 화 계통에 속하는 $\mathrm{SOD}$ 효소처럼 자유라디칼을 제거하는 항산화능이 있음을 말해 주고 있으며, $\mathrm{KAE}$ 의 $\mathrm{SOD}$-유사 활성능을 보고한 연구 결과와도 일치하였다(Kim et al., 2010). KAE의 이 같은 항산화능은 본 실험에서 행한 $\mathrm{DPPH}$-라디칼 소거능의 분석과 함께 $\mathrm{KAE}$ 의 항산화능을 뒷받침해주고 있다. SOD 항산화 효소는 인체의 대사과정 
중 생성된 $\mathrm{OH}^{-}$나 $\mathrm{O}_{2}^{-}$와 같은 자유라디칼을 $\mathrm{H}_{2} \mathrm{O}_{2}$ 로 전환하 고 물로 변화시켜서 인체에는 아무런 영향을 미치지 않 게 한다(Linke et al., 2005). LP 억제능 조사에 대한 KAE는 $180 \mu \mathrm{M}$ 과 $200 \mu \mathrm{M}$ 의 처리 농도 모두에서 대조군에 비하 여 LP 활성을 현저히 감소시킴으로써 유의한 LP 억제능 을 보였다. 본 연구 결과는 $\mathrm{KAE}$ 에 대한 $\mathrm{LP}$ 억제능을 보 고한 연구 결과와 일치하였으며(Kim et al., 2010), 본 결과 는 $\mathrm{KAE}$ 가 막의 구성을 이루고 있는 막지질의 산화를 방 지하는 항산화 작용이 있음을 제시하고 있다. 이 같은 현 상은 $\mathrm{KAE}$ 에 함유되어 있는 flavonol을 비롯한 anthocyanin 및 iron과 같은 항산화 효능이 높은 flavonoid 계통의 성분 들에 의해 LP 활성이 억제된 것으로 생각된다(Wang et al., 2006). LP 활성의 측정은 lactate dehydrogenase (LDH) 활성 과 함께 막손상 정도를 측정할 수 있는 대표적인 정량 분 석 방법의 하나로 알려져 있다(Hah et al., 2005). 이상의 결 과로부터 $\mathrm{KAE}$ 와 같은 성분은 허혈과 같이 산화적 손상과 관련된 병변에 대한 치료제로, 항산화제 약물개발을 위해 활용가치가 클 것으로 생각된다. 그러나 천연성분에 대한 항산화 측면에서의 생리 활성 분석은 검정성분에 대한 생 화학적 분석은 물론, 약리나 분자 및 구조적 측면에서 보 다 자세한 연구가 필요할 것으로 생각된다.

\section{ACKNOWLEDGEMENTS}

이 논문은 2017 학년도 원광대학교의 교비 지원에 의해 수행됨.

\section{CONFLICT OF INTEREST}

The authors declare no conflict of interest.

\section{REFERENCES}

Blois MS. Antioxidant determination by the use of a stable free radical. Nature. 1958. 26: 1199-1200.

EI-Sayed NH, Omara NM, Yousef AK, Farag AM, Mabry TJ. Kaempferol triosides from Reseda muricata. Phytochem. 2001. 57: 575-578.

Endoh M, Maiese K, Wanger J. Expression of the inducible form of nitric oxide synthase by reactive astrocytes after transient global ischemia. Brain Research. 1994. 651: 92-100.

Gates MA, Tworoger SS, Hecht JL, De Vivo I, Rosner B, Hankinson SE. A prospective study of dietary flavonoid intake and incidence of epithelial ovarian cancer. International Journal of Cancer. 2007. 121: 2225-2232.
Gracia-Lopez D, Cuevas MJ, Almar M, Lima E, De Paz JA, Gonzalez-Gallego J. Effects of eccentric exercise on NF- $\mathrm{BB}$ activation in blood mononuclear cells. Medicine \& Science in Sports \& Exercise. 2007. 39: 653-664.

Hah DS, Kim CH, Kim GS, Kim EG, Kim JS. Antioxidant effects of traditional medicinal plants on lipid peroxidation. Korean Journal of Veterinary Research. 2005. 45: 341-350.

Hamsten A, Eriksson P, Karpe F, Silveria A. Relationships of thrombosis and fibrinolysis to atherosclerosis. Current Opinion in Lipidology. 1994. 5: 382-389.

Jialal I, Devaraj S. Low-density lipoprotein oxidation, antioxidants, and atherosclerosis: a clinical biochemistry perspective. Clinical Chemistry. 1996. 42: 498-506.

Jung IJ. The effect of NMDA/glycin receptor antagonist, 7-chlorokynurenic acid on cultured astrocytes damaged by ischemialike condition. Journal of Experimental \& Biomedical Sciences 2009. 15: 355-362.

Kikuzaki H, Nakatani N. Antioxidant effects of some ginger constituents. 1993. Journal of Food Science. 58: 1407-1410.

Kim MS, Seo YM, Park ST. Antioxidant effect of kaempferol on cultured human skin fibroblasts damaged by methylmercuric chloride. Journal of Plants People and Environment. 2010. 13: 23-29.

Kim TY, Jekal SJ. Antioxidative effect of Chelidonium majus extract on cultured NIH3T3 fibroblasts injured by cadmium chloride of toxicant. Korean Journal of Clinical Laboratory Science. 2016. 48: 1-7.

Krizkova L, Nagy M, Polonyi J, Dobias J, Belicova A, Grancai D, Krajcovic J. Phenolic acids inhibit chloroplast mutagenesis in Euglena gracilis. Mutation Research. 2000. 469: 107-114.

Lee JC, Cho GS, Choi BO, Kim HC, Kim YS, Kim WK. Intracerebral hemorrhage-induced brain injury is aggravated in a senescence accelerated prone mouse. Stroke. 2006. 37: 216 -222 .

Lee JC, Cho GS, Kim HJ, Lim JH, Oh YK. Nam WW, Chung JH, Kim WK. Accelerated cerebral ischemic injury by activated macrophage/microglia after lipopolysaccharide microinjection into at corpus callosum. Glia. 2005. 50: 168-181.

Lee JC, Kim WK. Aging and stroke. Journal of Korean Gerontological Nursing. 2006. 16: 11-16.

Leung HWC, Lin CJ, Hour MJ, Yang WH, Wang MY, Lee HZ. Kaempferol induces apoptosis in human lung non-small carcinoma cells accompanied by an induction of antioxidan enzyme. Food and Chemical Toxicology. 2007. 45: 2005-2013.

Li YL, Gan GP, Zhang HZ, Wu HZ, Li CL, Hung YP, Liu TW, 
Liu JW. A flavonoid glycoside isolated from Smilax china L. rhizome in vitro anticancer effects on human cancer cell lines. Journal of Ethnopharmacology. 2007. 113: 115-124.

Linke A, Adams V, Schulze PC, Erbs S, Gielen S, Fiehn E, MobiusWinkler S, Schbert A, Schuler G, Hambrecht R. Antioxidative effects of exercise training in patients with chronic heart failure: increase in radical scavenger enzyme activity in skeletal muscle. Circulation. 2005. 111: 1763-1770.

Luscher TF, Vanhoutte PM, Boulanger C. Endothelial dysfunction in hypertension, in Rubanyi G (ed): Cardiovascular significance of endothelium-derived vasoactive factors. Future New York. 1991. 20: 199-221.

Ma J, Luo XD, Protiva P, Yang H, Ma C, Basile MJ, Weinstein IB, Kennelly EJ. Bioactive novel polyphenols from the fruit of Manikara zapota (Sapodolla). Journal of Natural Products. 2003. 66: 983-986.

Marklund S, Marklund G. Involvement of superoxide anion radical in the oxidation of pyrogallol and a convenient assay for superoxide dismutase. European Journal of Biochemistry. 1974. 47: 468-474.

Oh YL, Choi YR, Chang BS, Jung IJ. Antioxidative effect of Portulaca oleracea L. extract on allergic contact dermatitis agent, copper in cultured human skin fibroblasts. Journal of Investigative Cosmetology. 2012. 8: 243-249.

Pellegrini-Giampietro DE, Cherici G, Alesiani M, Carla V, Moroni F. Excitatory amino acid and free radical formation may cooperate in the genesis of ischemia-induced neuronal damage. Journal of Neuroscience. 1990. 10: 1035-1041.

Schwartz SM, Foy L, Bowen-Pope DF, Ross R. Derivation and properties of platelet-derived growth factor-independent rat smooth muscle cells. American Journal of Pathology. 1990. 136: $1417-1428$.

Sellke FW, Armstrong ML, Harrison DG. Endothelium-dependent vascular relaxation is abnormal in the coronary microcirculation of atherosclerotic primates. Circulation Research. 1990. 81: 1586-1593.

Stanimirovic D, Satoh K. Inflammatory mediators of cerebral endothelium: a role in ischemic brain inflammation. Brain Pathology. 2000. 10: 113-126.

Verbeuren TJ, Jordaens FH, Zonnekeyn LL. Effect of hypercholesterolemia on vascular reactivity in the rabbit. I. endotheliumdependent and endothelium-independent contractions and relaxations in isolated arteries of control and hypercholesterolemic rabbits. Circulation Research. 1986. 58: 552-564.

Wang L, Tu YC, Lian TW, Hung JT, Yen JH, Wu MJ. Distinctive antioxidant and antiinflammatory effects of flavonols. Journal of Agricultural and Food Chemistry. 2006. 54: 9798-9804.

https://doi.org/10.15616/BSL.2017.23.4.339

Cite this article as: YW Son, YR Choi, YM Seo. Protective Effect of Kaempferol on Cultured Neuroglial Cells Damaged by Induction of Ischemia-like Condition. Biomedical Science Letters. 2017. 23: 339-347. 